\title{
VALAHOL A MILLIÓNYI KESUDIÓFA ÁRNYÉKÁBAN REJTEZIK EGY ORSZÁG: BISSAU CUINEA
}

\author{
ÍRTA ÉS FOTÓZTA: NAGY BENDECÚZ LÓRÁND
}

\begin{abstract}
Bissau az eddigi egyetlen afrikai főváros, ahol kerekesszékkel is halálfélelem nélkül lehet sétálni, a Ceiba Hotel előtt az utcán kesudiót rágva netet és időt lopni.

Bissau Guineáról korábban azt sem tudtam, hogy létezik. A fővárosban, Bissau Capital-ban most búcsúztam el Dom Alfredinho-tól, akinek a házában saját külön szobában, IKEA ágyban és lepedőn két napig majdhogynem felfoghatatlan luxusban pihentettem Marokkó és Szenegál között elfáradt agyam és meggyötört szívem-lelkem.
\end{abstract}

Mert Afrika, ha az ember nem kíméli önmagát, ha leereszkedik a hétköznapi élet fenekére, az bizony meggyötör!

Dom Alfredinho sikeres kerekesszékes DJ itt a fővárosban, saját tulajdonú több szobás házában vidám családjával középosztálybeli életet él. A felesége, Sabadu, olyan fekete, amilyet korábban még életemben nem láttam, pont mint egy ébenfaszobor. A nagy család óriási egyetértésben, boldogan veszekedve és pörölve, fülsiketítően hangosan éli az életét.

Fabian, a soförje Audival hozza-viszi, szakácsnő és cseléd lesi a család minden óhaját. Kedvenc rokonai és néhány barátja az év minden egyes napján beköszön a

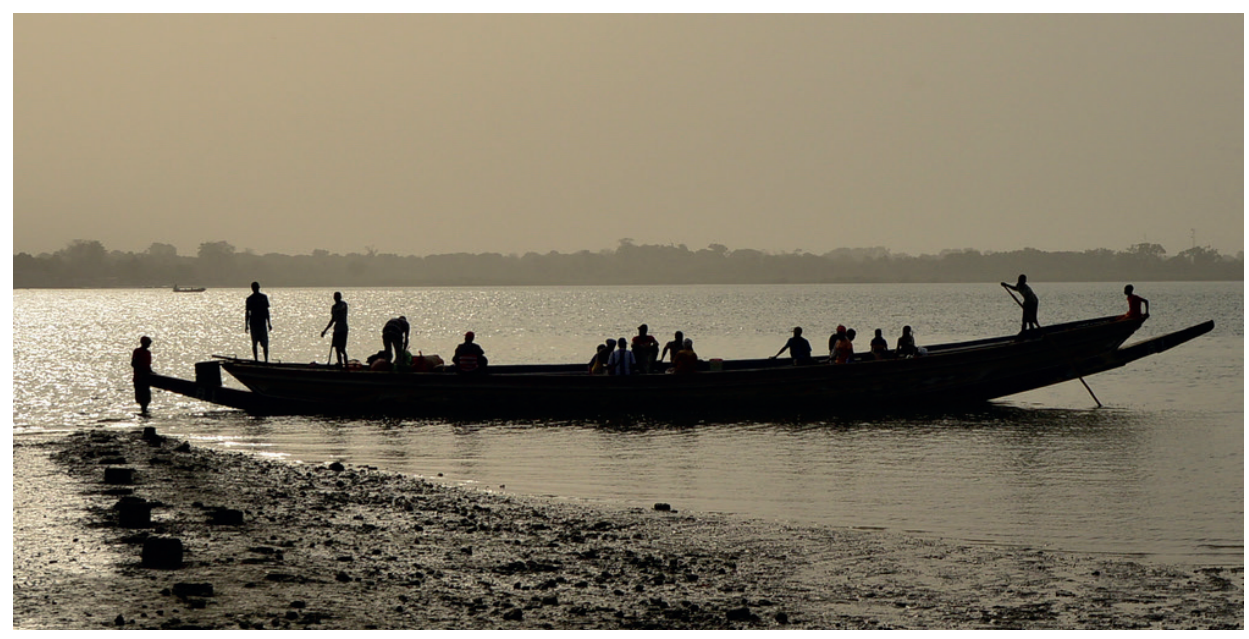



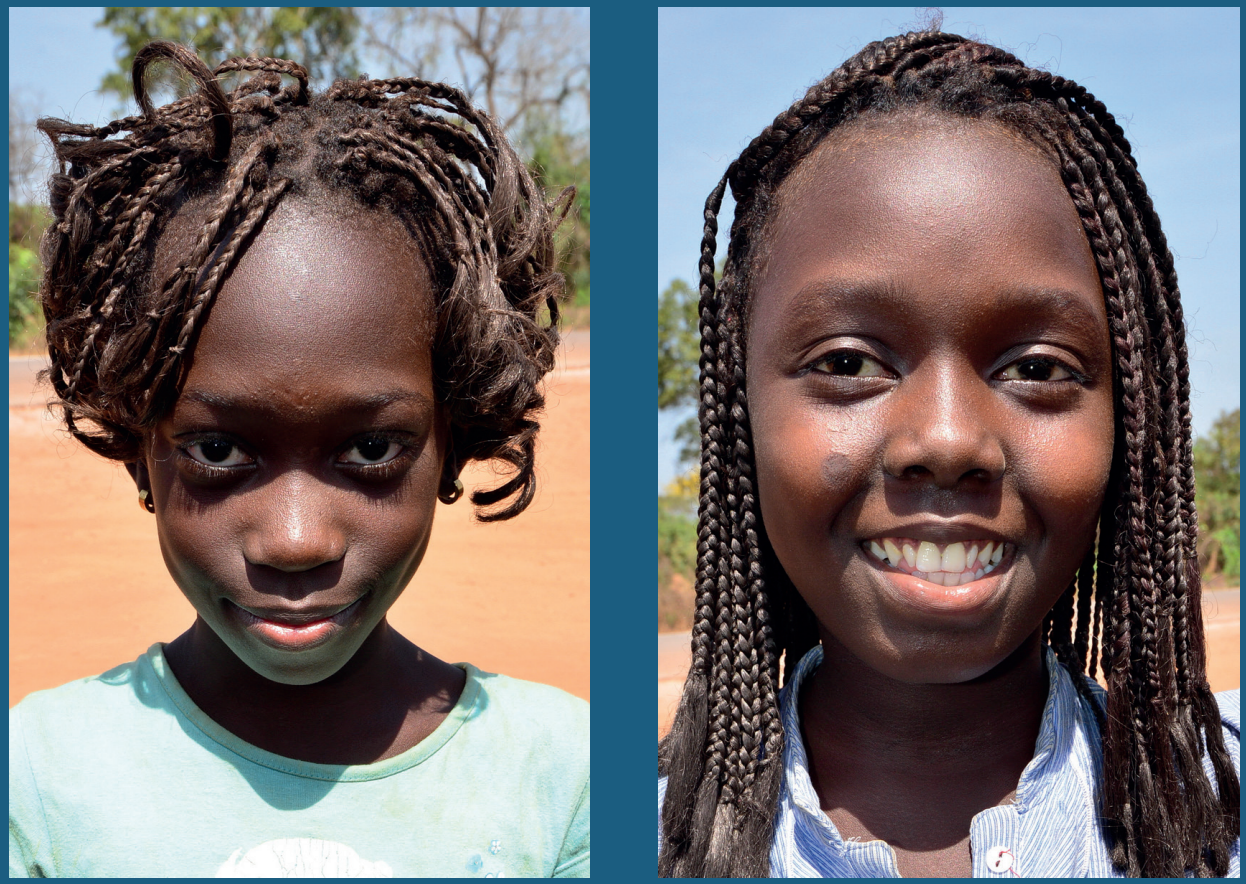

házba, ha nem sietnek megisznak valamit a konyhában, ha igen egy rövidke félórát ácsorognak az előszobában és beszámolnak egymásnak az utolsó nap alatt történtekről.

A sarkon Agostinho portugál önkéntes a motorja küllőit csinosítja, az erőd fala alatt hosszú szőrü fekete disznók túrják boldogan röfögve a kevés szemetet, a keselyűk üveges szemmel lustán lógnak alá az ágak közt, álmodom.

Ahogy az erőd kihalt vasárnap délutánján, a kopottas, foltos flaszteron a túravezetö tiszte mellettem verejtékezik..., óhatatlanul marquezi vagy rejtői hősnek érzem magam.

Dom Alfredinho meg akarta venni a Jimny-t, de végül letett róla, mert túl magas neki. Tegnap bátorítottam, hogy próbálja ki itt a városban.

Egy óra alatt körbefurikáztuk a városban a kedvenc helyeit, néha megálltunk különböző házak és kocsmák elött, Dom Alfredinho hangosan bekurjantott, majd büszkén feszített a volán mögött a hüledező barátai elött. Eleinte furcsállottam a manővereket és a vezetési stílusát, de megnyugtatott, hogy mindketten élünk és a kocsi is egyben van. Én még nem tudtam, ami nekik nyilvánvaló volt, valószínúleg restellte, hogy még soha nem ült a volán mögött, ezért nekem sem említette, így majd ötven évesen, élete első autóvezetési élményébe nagy önbizalommal vágott 

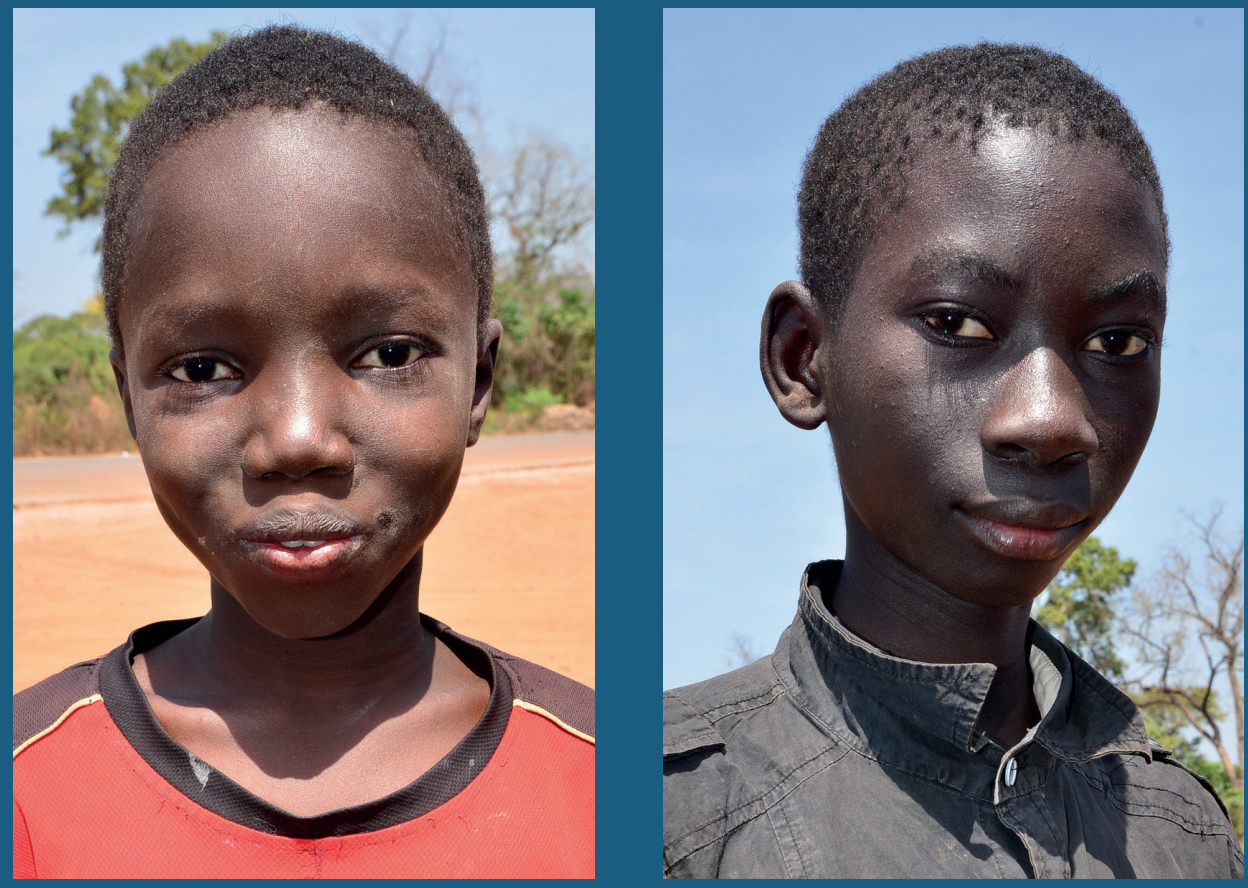

neki. Amikor fülig érő szájjal leparkolt a háza előtt és kinyögte, hogy ez volt az első, azt gondoltam, hogy megörült, majd inkább, hogy le az összes kalappal elötte, föleg úgy, hogy gyermekbénulás miatt egyik lába sem mozog és a jobb kezével maximum egy anorexiás legyet tud elhajtani.

Ma reggel Fabio kedves meglepetésként lemosta az autómat, nyomban ki is derült, hogy a több hetes vörös por és kosz alatt azúrkék az alapszíne. Minekutána alaposan kipihentem magam, úgy érzem, hogy itt Bissauban, a fövárosban lezárult utam második etapja, következhet a harmadik. Elindulok Bolama-ba, egy távoli szigeten fekvő hajdani portugál gyarmati szellemfóvárosba, majd onnan tovább az ország délkeleti csücskébe egy parányi nemzeti parkba csimpánzokkal és elefántokkal ösmerkedni. Majd, ha azt is meguntam vagy belefáradtam, a Guneai Köztársaság, itteni nevén Guinea-Conakry következik, az utolsóelőtti ország a végcél, Ghána előtt. 

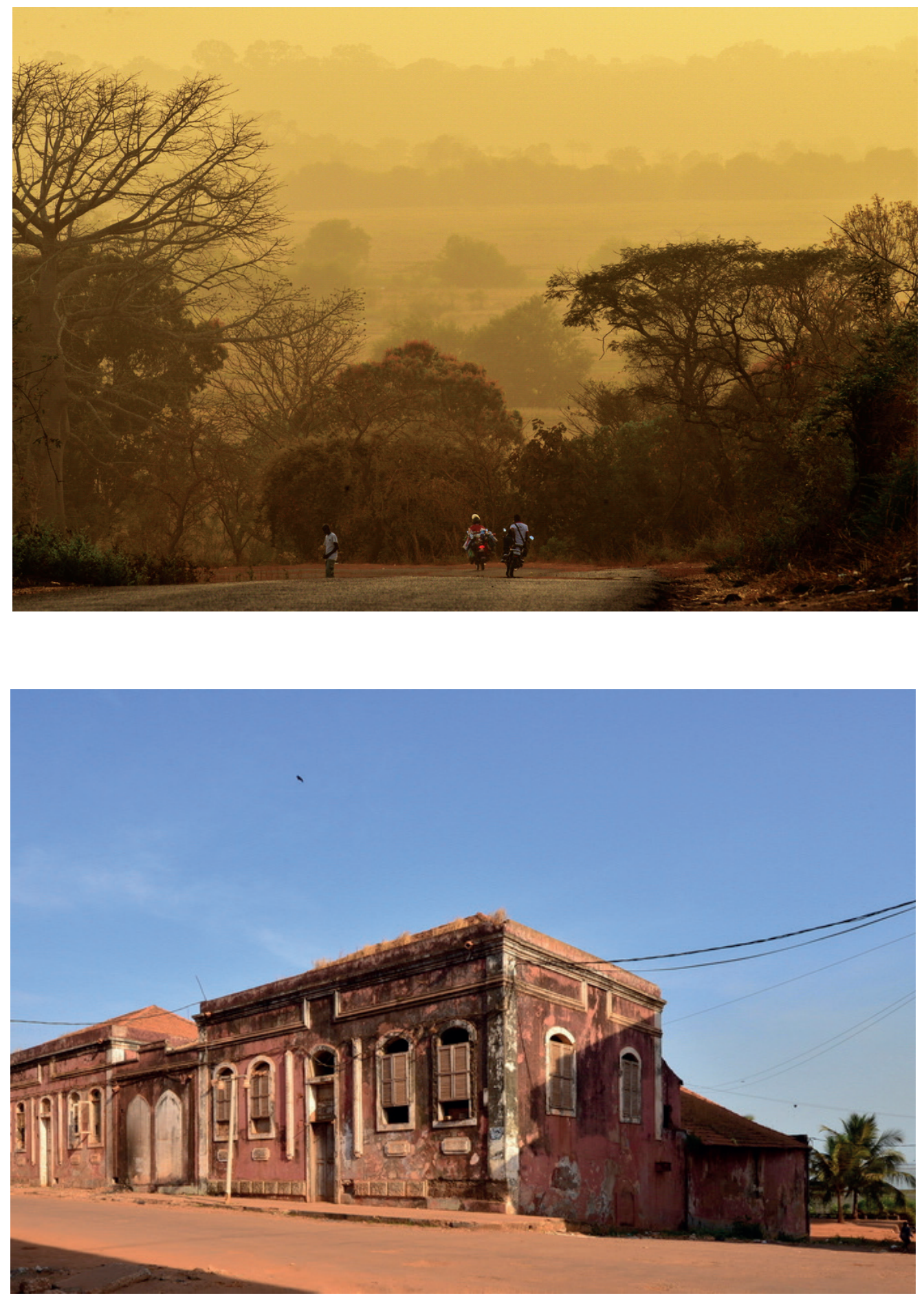

$48 \quad$ Afrika Tanulmányok 


\section{Úton Bolama felé megtanulom, hogy a fekete kátyú jó, a vörös a Föld közép- pontjáig ér.}

A dzsungelben és a bozótban döcögve az ember mindig örül a következő falunak, és bár első blikkre tizenkettő egy tucat, kis idő után az utazó rájön, hogy mégsincs köztük két egyforma. Pár óra csontszétrázó futamot követően Fulacunda-ba érve a központi poros flaszteron megállok a vegyesbolt elött. Választási kampány van, szembántóan új és Bissau zöld és kék alapszínétől eltérő színes plakátok virítanak mindenütt a kopottas falakon. Közel parkolok, de annyi helyet mindig hagyok, hogy mindenki elférjen. Még nem szállok ki, pár percet várok, a csontjaim és a beleim a helyükre kerülnek, a lelki por is leülepszik, majd kidugom vigyorgó fejem az autó ablakán, és mint a mekdrájvban, a nemes arcú fiatal muzulmán kaftános boltosnak bemondom, hogy tejes kávét szeretnék, aminek itt „café-foté” vagy „café-branco” a neve, mindkettő fehér, világos kávét jelent. Amikor nem frissen fözött ébresztő-lötytyöt kérek, akkor 'nescafé-foté'-t kell bemondani.

A kezébe nyomom az amerikai narancssárga rozsdamentes acél poharat és várok, várok, várok... Általában forró víz, tej, tejpor és/vagy kávé nincs, itt most épp mindegyik hiánycikk. A boltos szétküldi az autó körül lebzselő gyermeksereget, hogy szerezzenek forró vizet, akik sikertelenül nyargalnak körbe-körbe a vörös porban, így beruházok pár szaudi tejkonzervre és előkotorom a rossz időkre tartogatott kávévésztartalékot. A kedves és segítőkész boltost is megkínálom, némán beszélgetve szürcsölünk.

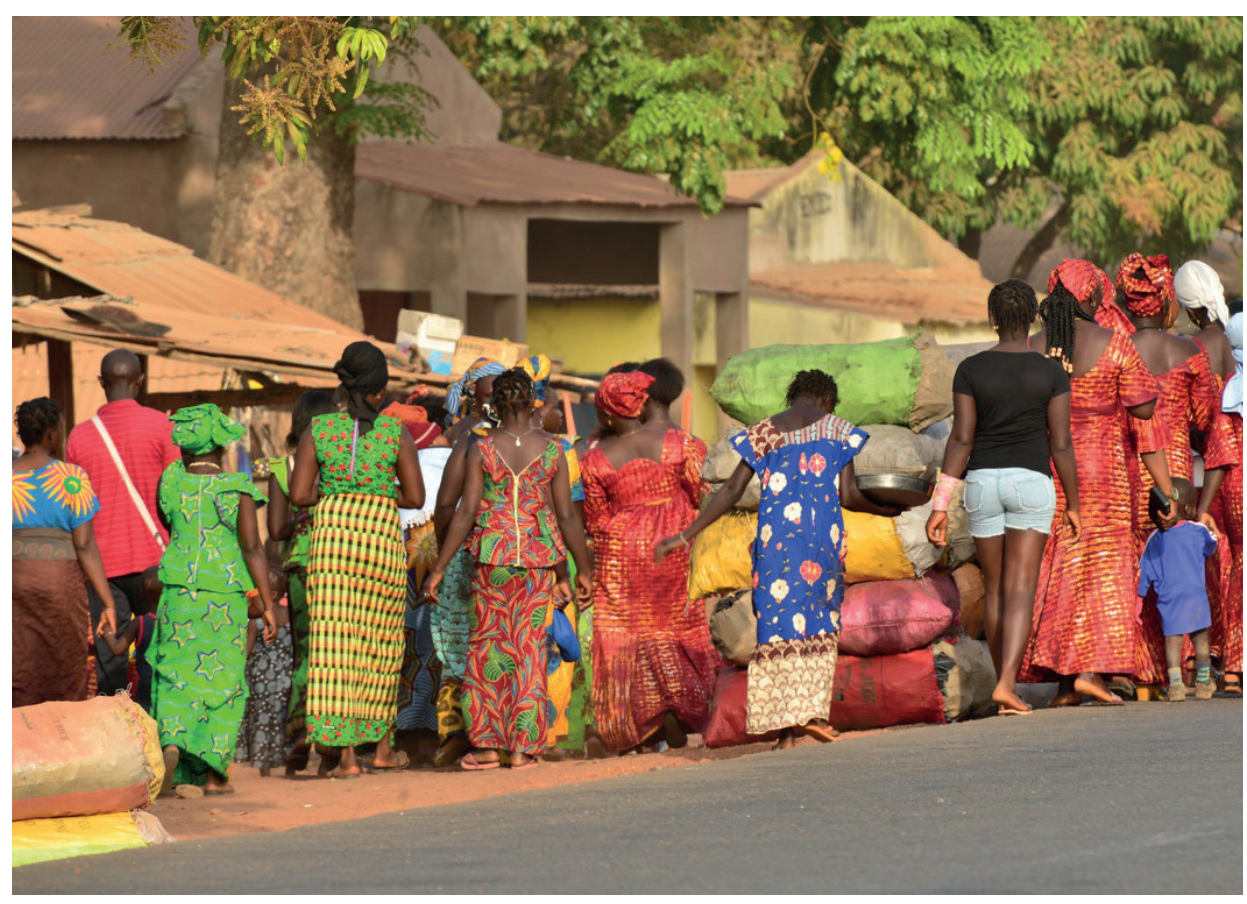

Nagy Bendegúz Lóránd: Valahol a milliónyi kesudiófa árnyékában... 
A sikerélmény és a kávé hatására, ami engem valamiért mindig elálmosít, megszokott mozdulattal vágom ki az ajtót, elégedetten döntöm hátra az ülést, és az ajtónyílásban matató kíváncsi koszos kiskezek neszezése hamar álomba ringat... pár nappal később Sao Joao-ból visszafelé, mert az ember a szokásainak a rabja, újfent megállok az én 'boltom' elött. A kereskedő őszinte örömmel az arcán fogad, megölelget, kifaggat, égre tartott karokkal hüledezik, hogy merre jártam. Feltöltöm a Sao Joao-ban majdnem nullára redukálódott készleteket. A felesége vakító fehér abrosszal letakart alumínium lavórlábasban hozza az elemózsiát, leteszi a férfiak elé, majd földre szegezett tekintettel, szégyenlős léptekkel ballag el.

Musztafa ebédre invitál, a barátaival együtt körbeüljük a tálat, a tiszta jobb kezünkkel halas rizst lapátolunk az arcunkba, majd kerek-tele hassal nyúlunk el a párától ragacsos késő délutánban a bolt tornácán. A maradékot a gyermeket a csirkékkel megharcolva egy szemvillanás alatt eltüntetik. Estefelé nagyon kedvesen, a szokásos szeretetteljes erőszakos módon marasztalnak. Musztafának próbálom elmagyarázni, hogy tényleg jól éreztem magam velük, hálás és elégedett vagyok, de jobb szeretek kint az erdőben, a bozótban, a dzsungelben aludni, mert nekem ez az utazással járó veszélytelen kaland, hogy otthon is tudok házban aludni. Soha, senki nem érti, ezek a kemény emberek pedig többnyire halálra vált arccal veszik tudomásul, hogy az erdőben fogom eltölteni az éjt, amitől ők jobban félnek, mint a gyehenna tüzétől. Nem értjük egymást, de elfogadjuk a másik véleményét. Bepattanok a székből Jimny-be, az összecsukott kerekesszéket áthúzom a lábamon, a

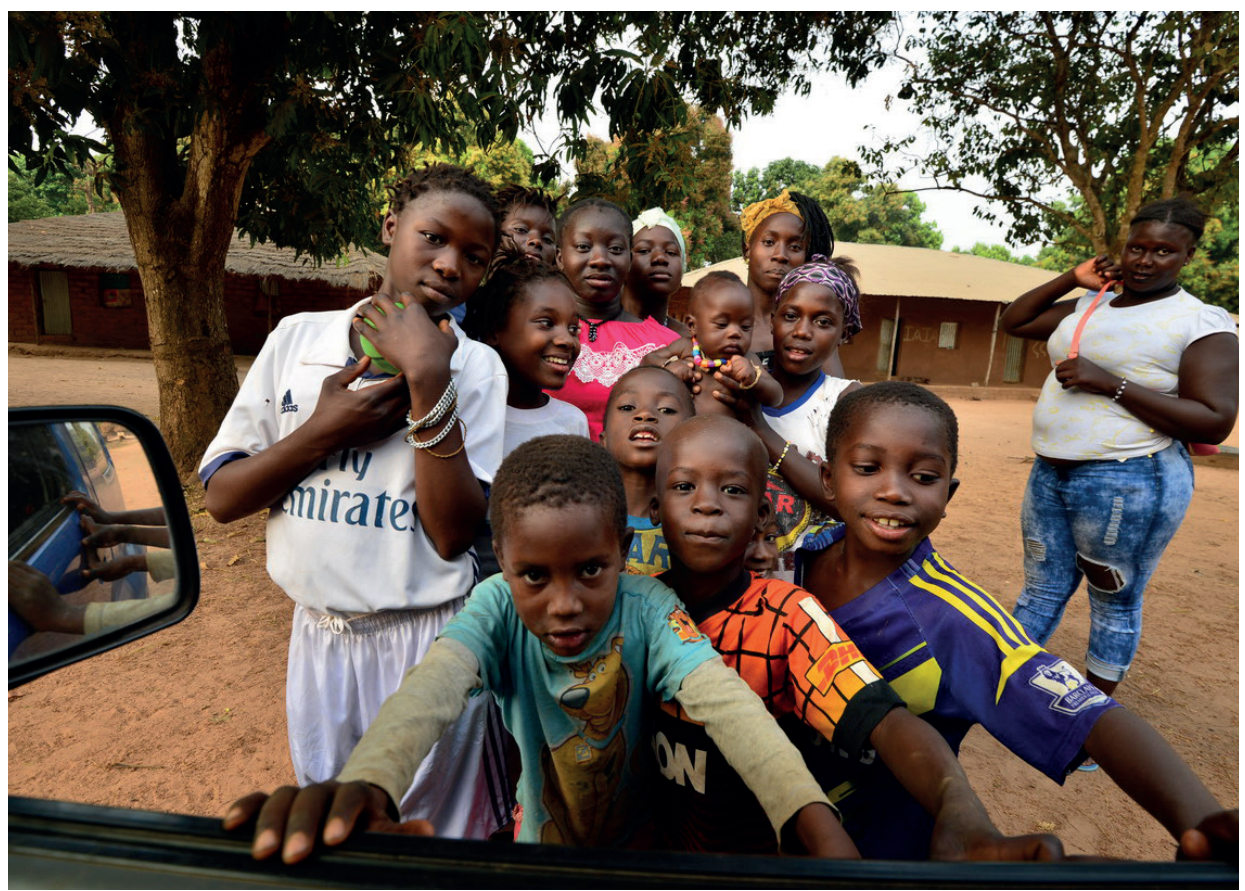



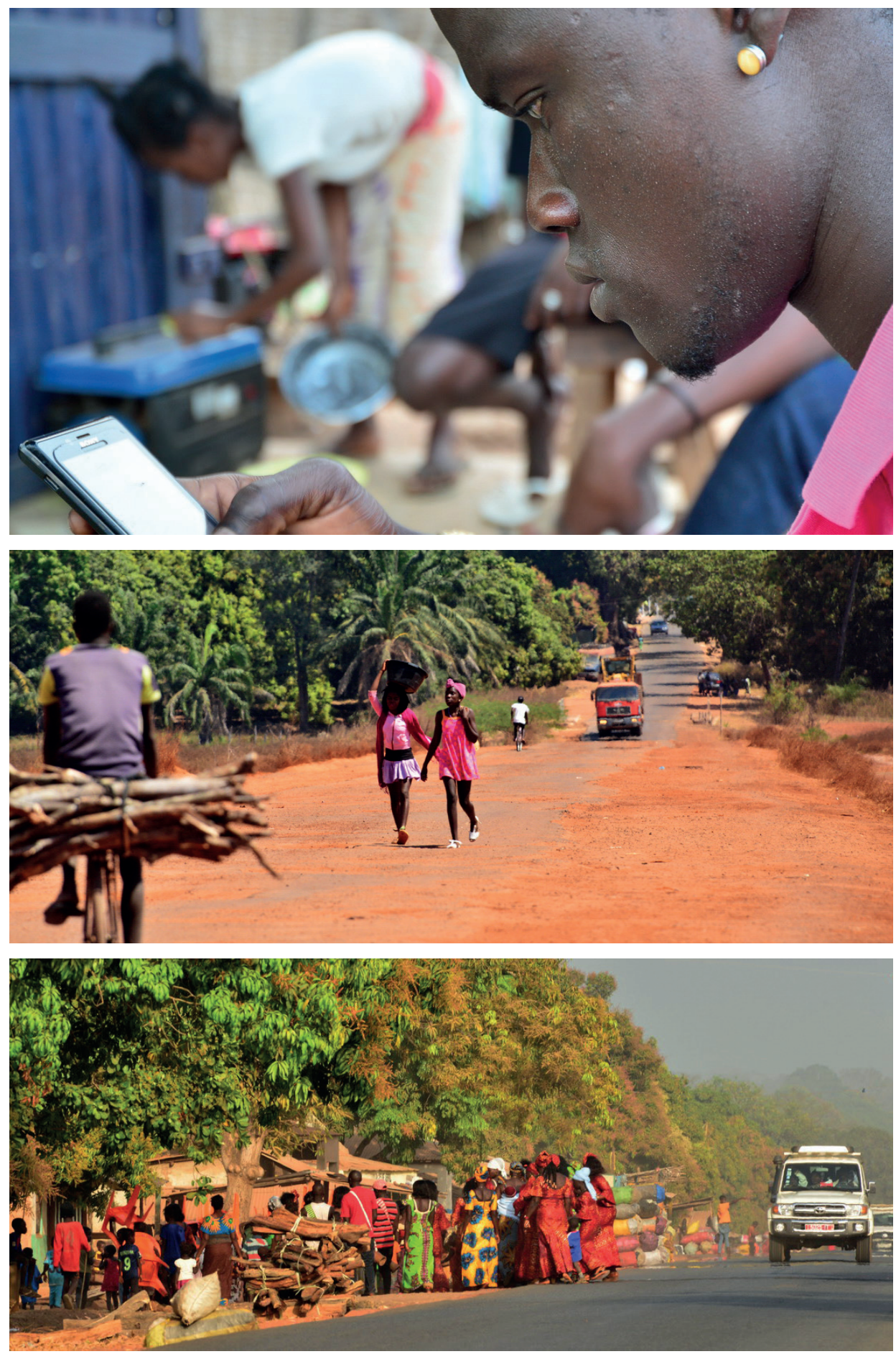

Nagy Bendegúz Lóránd: Valahol a milliónyi kesudiófa árnyékában... 


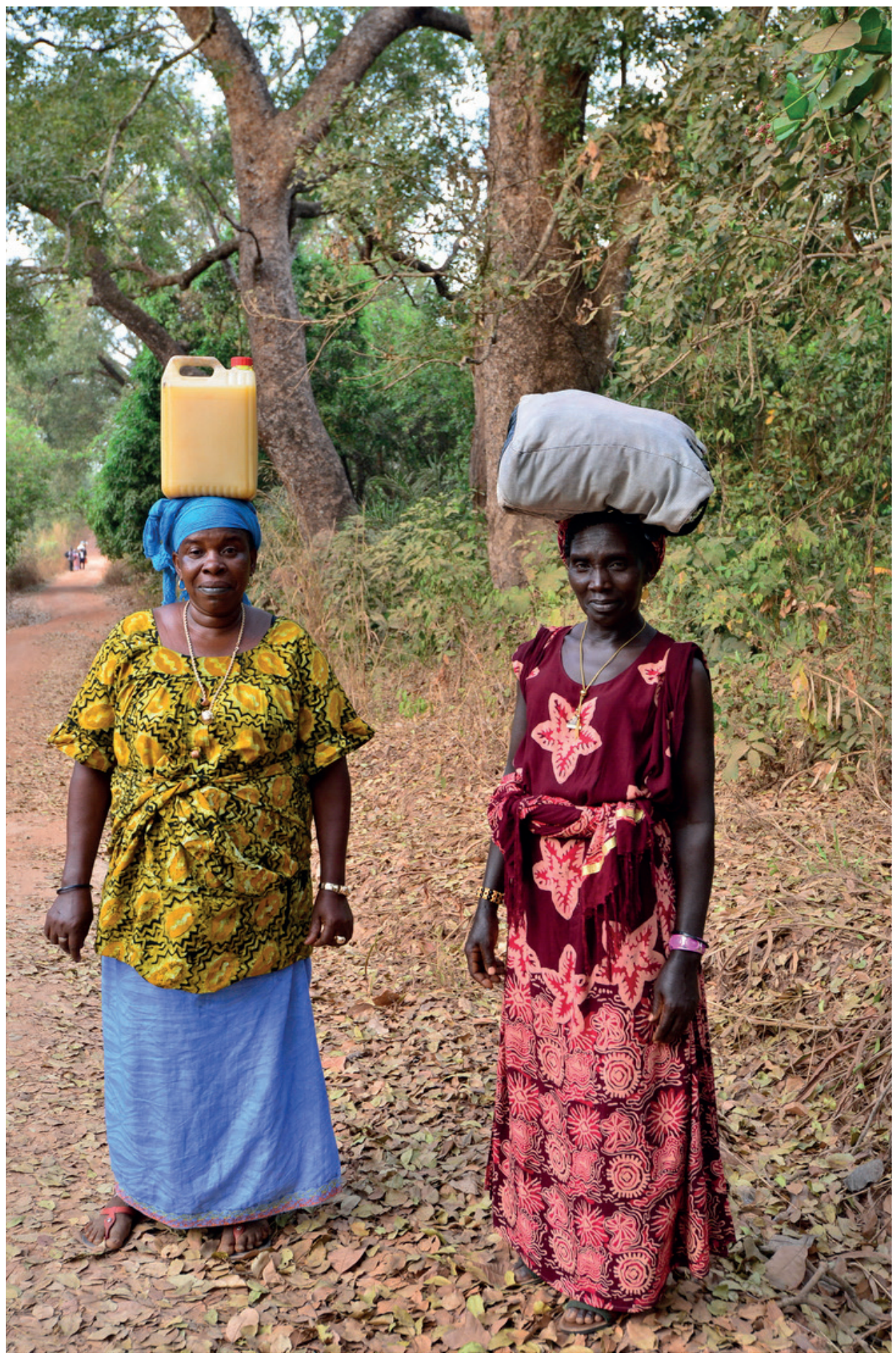

52 Afrika Tanulmányok 
jobbegyen megforgatom és irányba állítom, három irányba gumipókkal jó alaposan kikötözöm, az ajtó felöl még hálózsákkal is kitámasztom, a lábaimat is, hogy ne verjem még jobban össze, kikötözöm, beröffintem a mindig pöccre induló kis ezerhármas benzines kávédarálót, ami egy kevés kék füsttel jelzi, hogy indulásra készen állunk, majd nekilódulunk az esti kátyútangónak, ami gyakran inkább break-dance.

\section{Nem bánom a temérdek kráternyi kátyút, míg közte autónyi egérút is vezet.}

Úton Sao Joao felé, aholkomppal vagy piroggal fogokátkelniBolama-ba, arégigyarmati fövárosba, egész nap a betonkeménységủ vörös földúton, a ,terra batida'-n zötykölődve jólesik megpihenni Wanadin falujában. Estére érve az első háznál félájultan engedem el a gázt és a kormányt, amibe egész nap kapaszkodtam, amire a kis kék benzinmotoros bádog tyúkketrec, japán nevén Suzuki Jimny, a napközbeni bringás-, helyenként gyalogostempóról nyomban nullára lassulva ragad bele a vastag kesudiófalevél avarba. Az első ház előtt a tornácon Sanquinha Mané gazda jóvoltából számtalan pohár tea és egy kis tányér halszálkás rizs elfogyasztása után hullafáradt testemet további kezelésre átadom a holdvilágot kedvelő apró fekete legyeknek, a melgáknak. A melga csípése egyben a legjobb fogyókúra is, mert az elkövetkező napokban legszívesebben levájtam volna a bőröm, az alatt lévő zsírt majd az izmokat, mindent, le a csontig, annyira rettenetesen viszket. Wanadinban, Sanquinha Mané gazda hátsó kertjében néha felriadok, hajnali kettőig felváltva harcolok a melgákkal és a miniatür tigriscsíkos vérszívó moszkítókkal, majd feladom, kikászálódok a tábori ágyból, átbotorkálok a Jimny-be, de az is tele van szúnyoggal és melgával. Ezek az apró dögök szó szerint megesznek és ráadásul nevetve dünnyögnek hozzá.
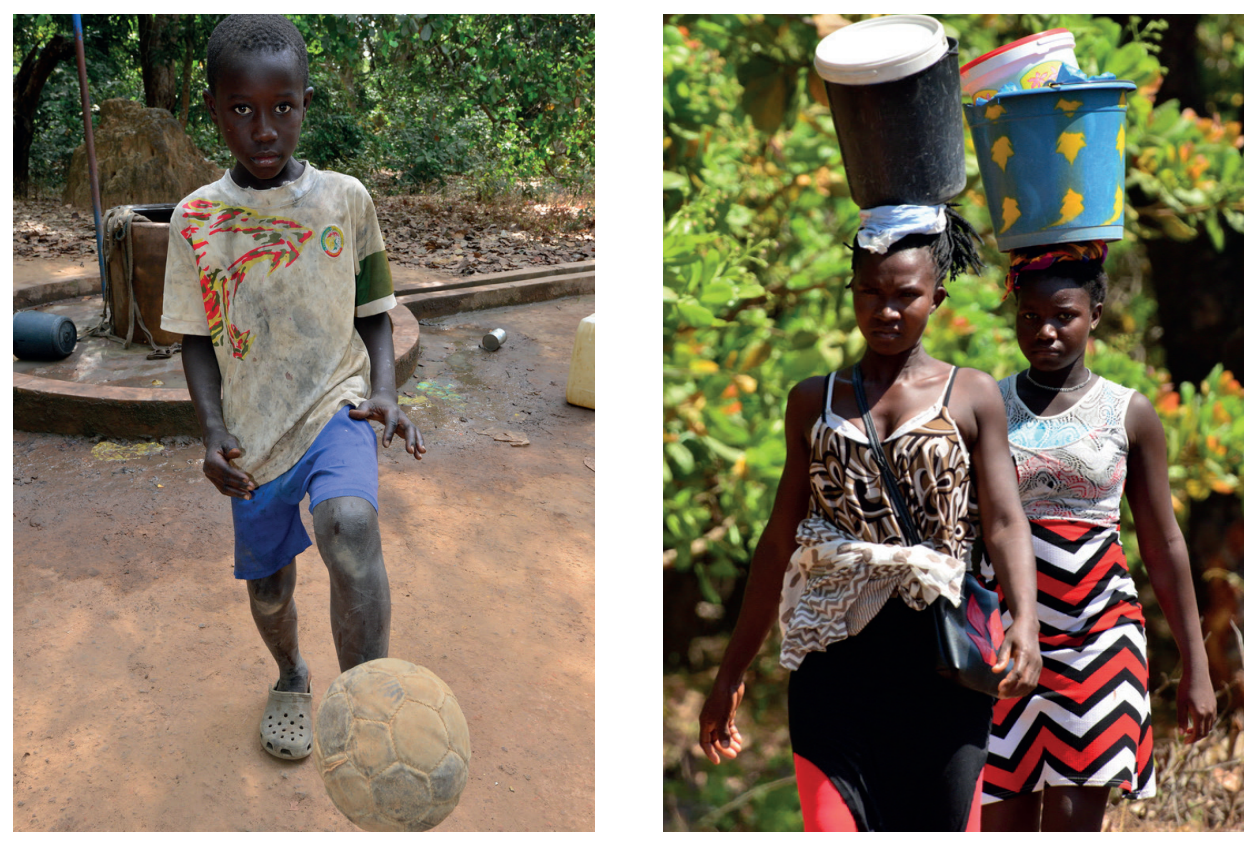

Nagy Bendegúz Lóránd: Valahol a milliónyi kesudiófa árnyékában... 
Reggel nagy ricsajra ébredek, a kút melletti lepusztult termeszvár lábánál versenyt mosnak a lányok, néha egy ugatásszerủen goromba, öblösebb női hang jól leteremti őket, mire egy ideig csak a kút nyikorgása, a ruhák és a kínai mủanyag mosódeszka csuszatolása hallatszik. A felkelő nap elüzi az éjjeli miniatür támadókat, kinyitom az ajtót, konstatálom, hogy a falufönök botjára támaszkodva figyel, köszönt, megbámulja a szokásos reggeli rutinomat, majd teára invitál.

A lányokat megkérem, hogy mossák ki az én ruhámat is. Zavartan nevetgélnek, semmi akadálya, azt sem bánják, ha készítek róluk pár képet. Mané Úrral és pár tiszteletreméltó falubeli öreggel a mangófa alatt a ház hủvös vályogárnyékában délig teázgatunk, beszélgetünk, a ruhák is megszáradnak közben. Elindulok, a dzsungelből autószélességüre kiirtott, vízmosásokkal szabdalt sáv, amit az egyszerüség kedvéért útnak nevezek, egyre rosszabb lesz, lépésben kerékröl-kerékre ugrálva haladok. Úgy látszik ide még nem ért el a választási kampány út- és irányegyengető bulldózere. Nova Sintrában megcsodálom a dzsungel mélyén büszkén feszítő vadonatúj vasbeton piacot, még rámpa is van, igaz kissé meredek.

Egy mangófa árnyékában ebédelek: a szokásos öt dirhamos marokkói halkonzerv, két kis fonnyadt paradicsom, egy banán és tejes kávé a mai menü az önkiszolgáló Jimny kantinban. A falu közepén az út elágazik, a MapsMe utasításainak megfelelően, bár a szélesebb, járható út balra vezet, nagyot sóhajtva jobbra fordulok a gyalogos csapásnál alig szélesebb vörös akadálypályára. Kora délután már úgy

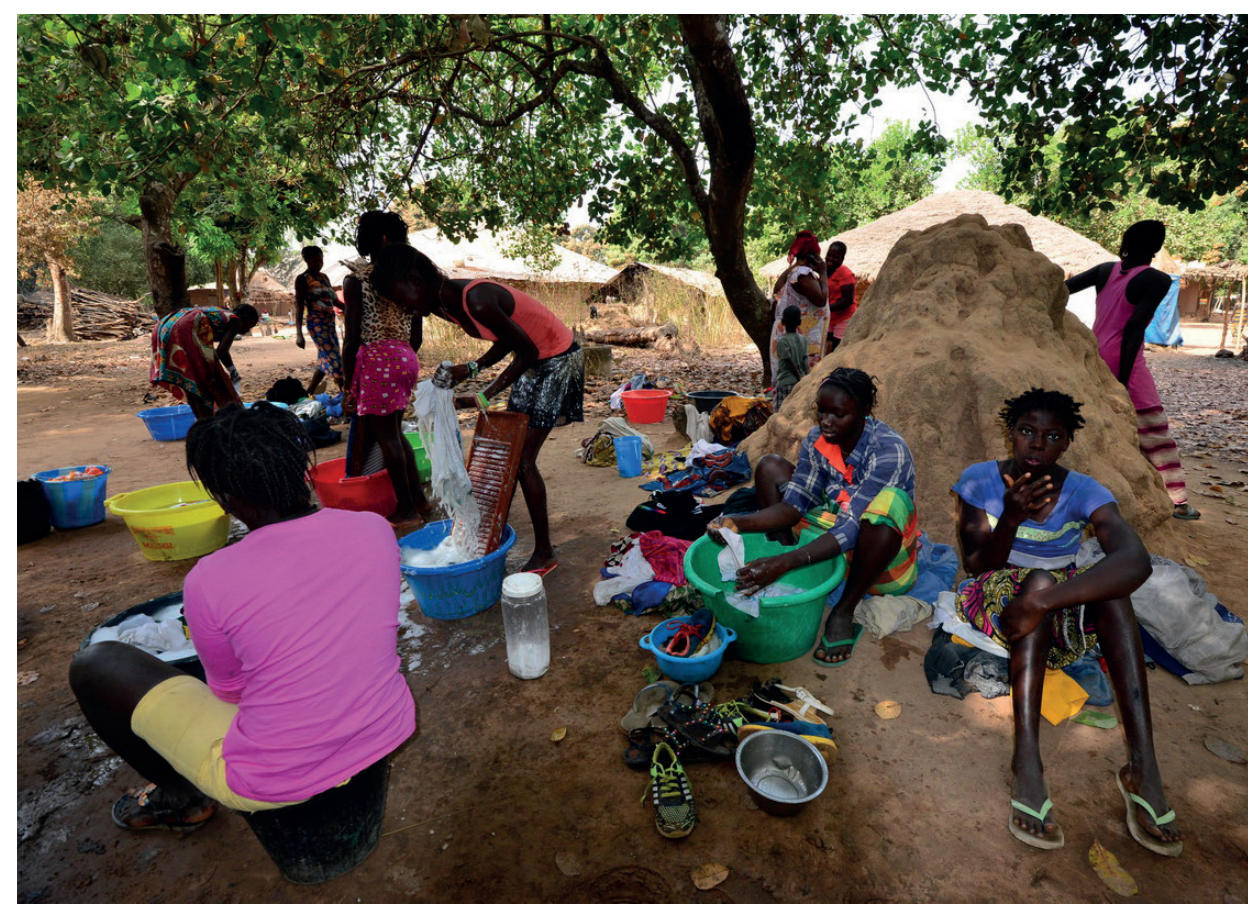


érzem magam, mint akit tizenkét menet végén sem ment meg a gong, de hirtelen az út véget ér, Sao Joao-ban a víznél koppanok, a kikötőben a kompot keresem. Onnan lehet tudni, hogy ez a kikötö, hogy az út, a szárazföld egy meredek letöréssel véget ér, itt már muszáj vízre szállni, a partot jobbra és balra a végeérhetetlen, áthatolhatatlan mangroveerdő-zöld fal szegélyezi.

Néhány kereskedő és iskolás várja a pirogot, angolul nem beszélnek, de annyit már értek kreolul, hogy nincs menetrendszerü komp, telefonon kell Bolama-ból megrendelni. Megcsodálom az évszázados portugál kutat, ejtőzök az árnyékban, tulajdonképpen mérgesnek is kellene lennem, mert Bissau Capital óta mindenki azzal hitegetett, hogy itt, Sao Joao-ban lesz menetrendszerinti komp.

Estefelé kedves férfihang angolul ébreszt. Matoto angoltanár, Maliból menekült el pár éve az északi konfliktusok elöl, itt lakik a víz mellett, a part melletti düledező raktárépületeket őrzi, fizetséget nem kap, de legalább van hol meghúznia magát. Évek óta illegális menekültként él Bissau Guineában, és hogy ne toloncolják vissza Maliba, rendszeresen hónapszámra végez rabszolgamunkát az elöljáróknak, kormányzóknak, kereskedőknek, mikor-kinek. Sao Joao-t szereti, ugyan itt is ingyen dolgoztatják, de itt legalább nem verik, a falufönök első felesége szigorúan tiltja a hagyományos erőszakot.

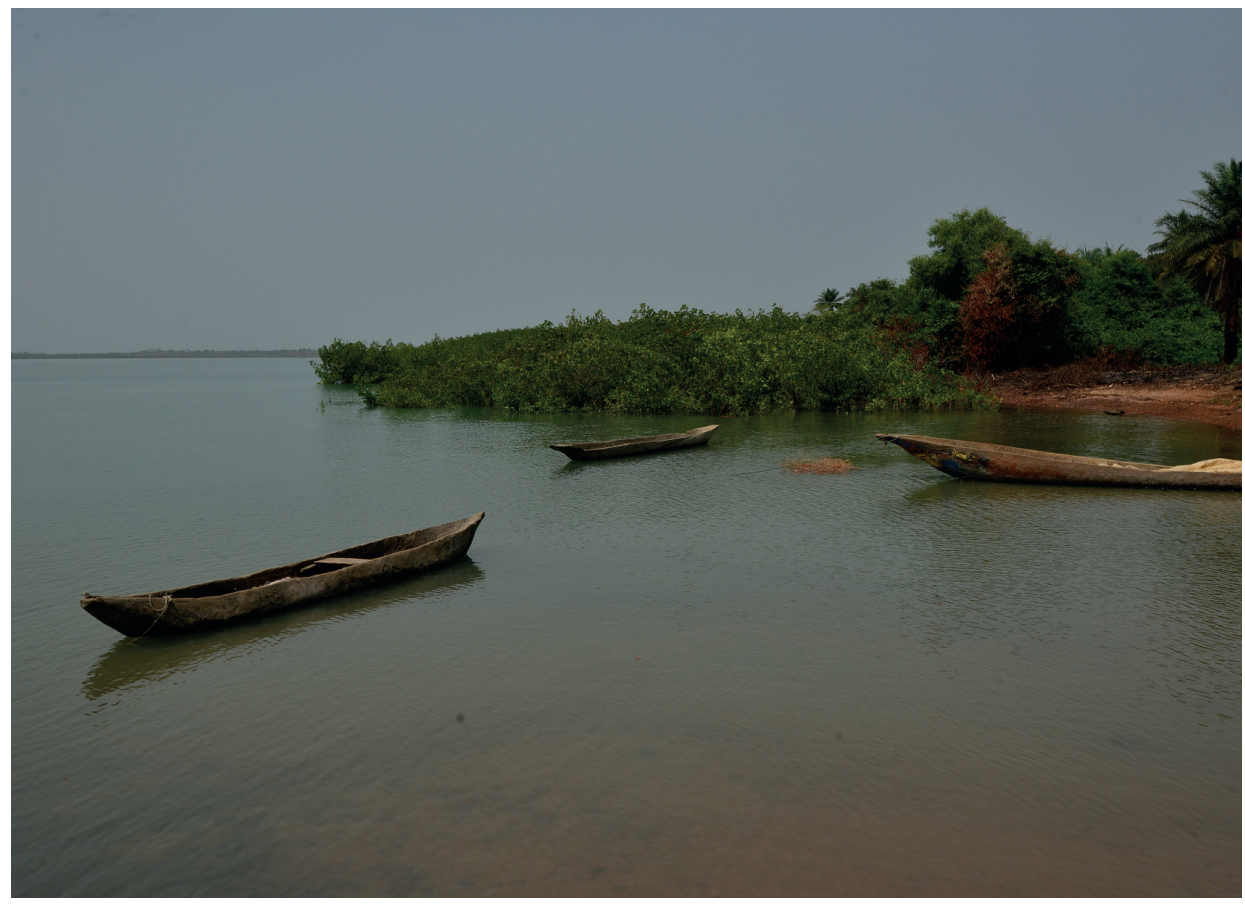


Megnyugtat, hogy ma már biztos nem lesz komp, talán pirog sem. Meghív, aludjak nála. A telekre nem vezet út, a Jimny fél kerékkel az árokban, a másikkal a betonhidacskán egyensúlyozva csörtet be az udvarra. Elámulok, ekkora betonplaccot Bissau főváros óta nem láttam, gyorsan kiszállok és futok is egy pár kört a székkel, mert gyakorlatilag napok óta nem szálltam ki a Jimny-ből, teljesen 'elzsibbadtak' pipaszár csirkelábaim. Matoto soványabb és szegényebb a templom egerénél, választékos angolsággal restelkedik, szabadkozik, hogy nincs mivel megkínálnia. Elbattyog a sötétben, majd kérges, de tiszta markában némi kidobott halmaradékkal tér vissza. Megfőzi a maréknyi rizst, jó sok pimont, csípős paprikát tesz bele, ami elnyomja az enyhén rohadt hal büzös mellékízét. Csipegetek a vacsorából, a nagy részét neki hagyom, bár nagyon aggódik, hogy éhes maradok. Nézz már rám, kétszer akkora vagyok, mint te, ráadásul ennek egy része tartalék! - nyugtatom meg nevetve. Elmesélem, hogy a rohadt hal egyébként sem mérgezö, Skandináviában még ma is előszeretettel eszik a viking elődök kedvenc eledelét, a surströmöt, a rohasztott heringet.

Reggel kerít egy mobilt, áttelefonál Bolama-ba. Rossz hír: a komp ára branco-knak, azaz nekem 50.000 CFA, majdnem 100 USD. Hüledezek, harcolok a hülye elveimmel, mennék is meg nem is: pénzem van, és ki tudja kerülök-e még valaha ide Sao Joao-ba, de végül hủ maradok eredeti filozófiámhoz, miszerint nem gazdagítom tovább valamelyik turistavéren élő kompos vámpírt nagyjából hat havi helyi keresettel. A betonozott sík placcon nagyon boldog vagyok, vörösporos svájci székemmel

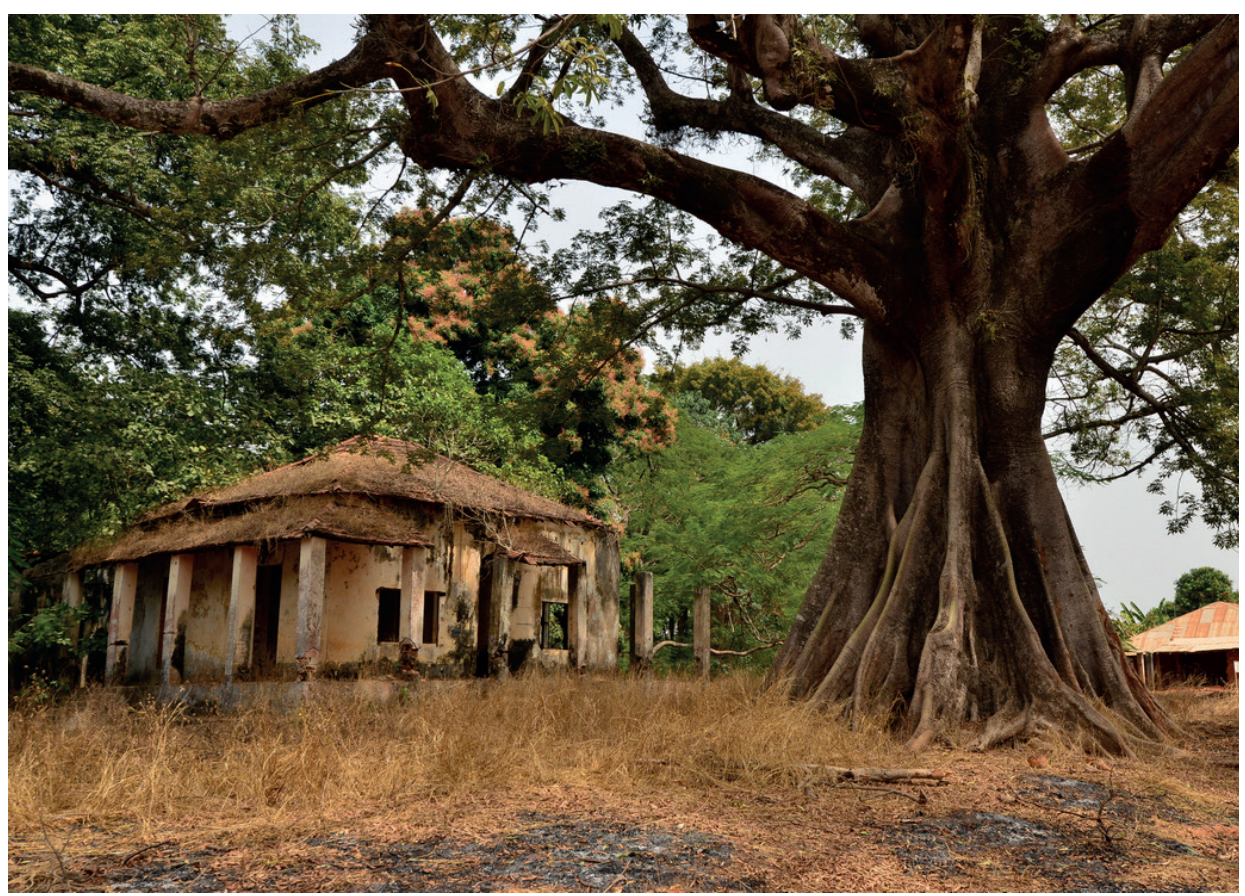


ficánkolok fel-alá. Előveszem a rejtett tartalékból a minőségi szaudi sủrített tejet, tejeskávét készítek kettőnknek, Matoto maghatódik, évek óta nem ivott ilyenfajta finomságot. Gondolatban megremeg a kezem, az ellátmányos láda mélyén Miskolc óta rejtezik egy-egy csomag Raffaello és Ferrero Rocher, de azt inkább gyermekeknek szánom, esetleg magamnak, ha elakadnék és a közelgő éhhalál elanyátlanítana.

Az autóból mindent kipakolok a placcra, rendszerezek, megajándékozom Matoto-t egy csomó hasznos holmival. Legjobban a kinyomtatott A4 Lonely Planet fejezeteknek örül, neki adom a Mali-t is, nem állja meg zokogás nélkül, amikor a hazájáról olvas. Rosszul lát, így neki adom a lidl-ös lupét is, boldogan silabizálja a sorokat, évek óta semmit sem olvasott. Öszintén és rettenetesen sajnálom Matoto-t, de ugyanakkor nem értem, hogy mit is keres itt. Az ő képességével bármilyen állást megpályázhatna Bissau-ban. Nyilván lelkileg megtört a sok hányattatásban, egy időre itt ragadt, jól érzi magát, senki sem bántja a vízparti házban, pár évre megpihen, angoltanításból szerez egy kis tőkét, bevásárol szárított halból, majd vízi úton leviszi Conakry-ba és onnan hazatér Mali-ba. Nagy vonalakban ennyi az évek óta halogatott terve. Matoto-nak adom az összes maradék CFA készpénzem, felballag a faluba, vesz halat és mindenféle finom zöldséget és gyümölcsöt, majd estefelé fenséges vacsorát rittyent.

Bolama-ba ugyan nem jutottam el, de Sao Joao-ban nagyon kedves emberekkel ismerkedtem meg. Reggel összepakolok és egyszemélyes vert seregként vonakodva, de elindulok visszafelé, az ország szíve felé. Nagyon nem akarózik elindulni, haladni kifelé a faluból, minden alkalmat megragadok a lassulásra, megállásra, bámészkodásra. A falu közepén gyökeret ver a gázpedál, itt áll ez a csodálatos elhagyatott portugál gyarmati ház, arra vár, hogy valaki megmentse végre. Alaposan szemügyre veszem, amennyire a bozót engedi, körbejárom autóval, időközben vizesdemizsonokkal felpakolt teherhordó kerékpárján szó szerint befut Matoto is, mert hallotta, hogy még mindig a faluban ejtőzök.

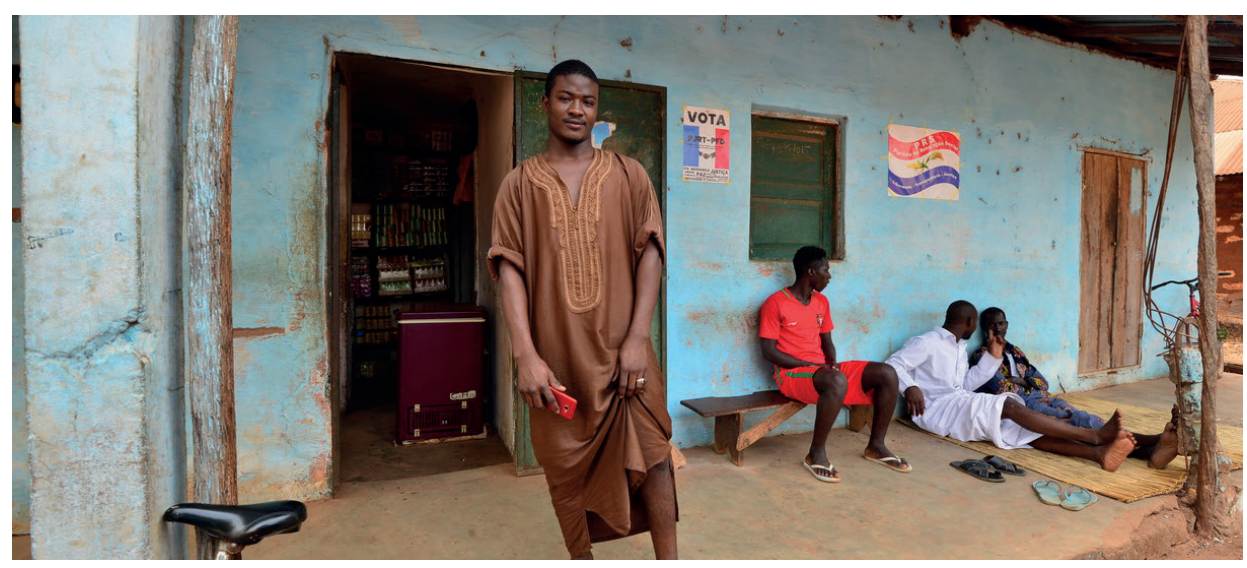

Nagy Bendegúz Lóránd: Valahol a milliónyi kesudiófa árnyékában... 
Nem tudja, hogy mi a helyzet ezzel a házzal, egy gyermeket elszalajt a falufőnökért. Mire megérkezik, tíz dollárért a kisbolt összes kekszét és dobozos kóláját megveszem és az elöljáró családjának ajándékozom, Matoto szerint így sokkal könnyebb lesz tárgyalni. Nagyon tetszik neki az ötletem, hogy hostel-kávéház-könyvtárkönyvesbolt ésatöbbi lehetne ebböl a csodás évszázados zöld romos kőhalmazból. Kiderül, hogy állami, védett tulajdon, a bolamai kormányzóval kellene személyesen beszélnem, itt ez a szokás, és ha szimpatikus vagyok neki, akár ingyen is a rendelkezésemre bocsájtja az épületet a hozzá tartozó több tíz hold földdel és további romos raktárépületekkel. Felvilágosítanak, hogy a kormányzónak felesleges írni, hívni is az, mindenképp személyesen érdemes felkeresni. Repesek az örömtől, Sao Joao-ban maradok még egy pár napot.

Matoto szerint rendszeresen mennek pirogok át Bolama-ba, így reggel leparkolok a kikötőben a Jimny-vel. Matoto rendesen kirittyentette magát, valahonnan a romok alól a zsákjából egy öltönyt is elöhúzott, éjjel a faluban valamelyik asszony ki is vasalta, büszkén igazítja meg Mali nemzeti színü nyakkendőjét, mert az is van neki. Sokadszorra is döbbentem állapítom meg, hogy Afrikában mindennapos a már-már mágikus csoda. Apály van, a vízen lebegő nagypirogig hosszú és meredek, fekete iszapos, ingoványos terepen kellene lejutni, odaát szintúgy, és gyaníthatóan viszszafelé is ugyanez lesz a helyzet. Dühös vagyok, ez nekünk nyilván nem fog menni, kiabálok Matoto-val, hogy ö ezt tudta, és ha tudta, miért nem mondta. Nem érti, zavartan mosolyog, megszokhatta, hogy a fehér ember, még a kedvesebbje is, mindig dühöng valamiért. Feladom, számomra fizikai képtelenség átjutni Bolama-ba,

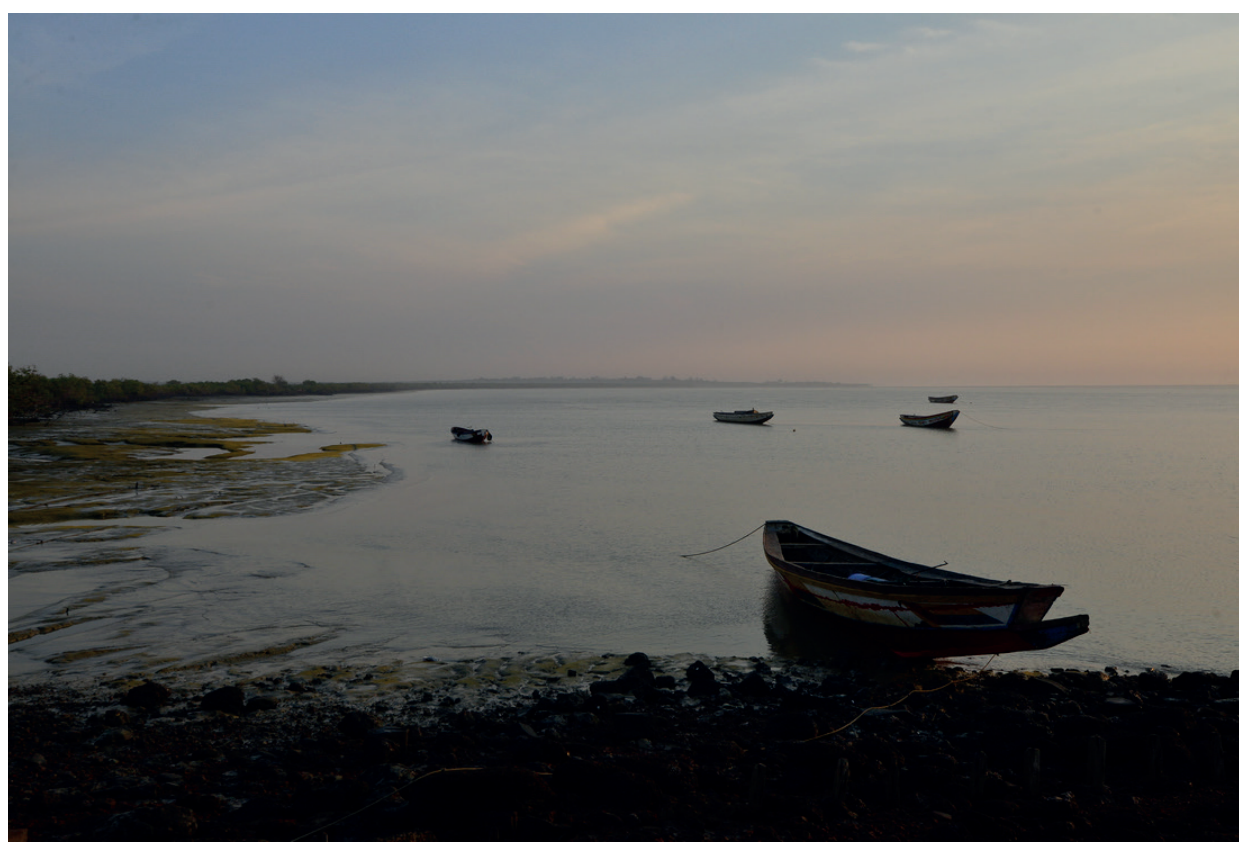


nem én fogok a kormányzóval tárgyalni, a romos udvarház a gigantikus elefántláb fák alatt további évszázadokon át zavartalanul hibernálva várhatja a megmentőjét. Néha annyira a vágyaimra és a tervekre koncentrálok, hogy egyszerüen elfelejtem, hogy kerekesszékes vagyok, és mint olyan, az afrikai dzsungel, bozót, homoksivatag és iszapos folyópart nem az én játszóterem. A természet viszont kevésbé feledékeny, a maga szeretetteljesen gyönyörüségében egyetlen napon sem felejt el erre az apróságra udvariasan-gorombán emlékeztetni. Nem baj, itt van nekem a Jimny, ami a lábam helyett benzinmotoros összkerékhajtású hüséges bádogcimbora, ami vagy aki zokszó nélkül vág neki a leglehetetlenebb kalandnak. Nehéz szívvel, de elhagyom Matoto-t, az öreg házat és Sao Joao-t.

Lehunyt zsibbadt aggyal néhány óra alatt a Jimny-vel átbukdácsolom a Fulacunda-ig vezető negyvenöt kilométernyi vörösporos akadálypályát. Ma nem akarom tudni, hogy az átlagsebesség gyalogosé vagy inkább nyugdíjas kerékpárosé volt. Minekutána Sao Joao-ban az összes, igaz nem túl sok ezer CFA-t Matoto-nak adtam, Fulacunda-ban a kedvenc boltosom elött megállok, sikertelenül akarok átváltani pár dollárt. Vizem van bőven, de éhes vagyok, igaz Bubá városa már nem lehet túl messze, ki fogom bírni. Az üzlet árnyékában szundikálok, amikor a kisbolt gondolatolvasó, mindig patyolattiszta kaftánt viselö fiatal muzulmán tulaja ínycsiklandón illatozó piláffal, salátával és teával kínál. Már majdnem rákezdeném, hogy nincs készpénzem, aztán észhez térek, nem akarom megsérteni, telerakom a bendőt.

\section{Ha még élsz és gurul az autó, minden milliomodik kátyú után útdíj következik, amit sokkal őszintébb lenne kátyú- és roncsdíjnak nevezni.}

Fulacunda után, az előző nehéz napok levezetéseképpen még pár kilométert döcögök, ugrálok, bukdácsolok az útnak semmiképp sem nevezhető retteneten, de hamarosan a választási kampányban bulldózerolt és hengerelt, sőt némely helyen zúzalékkal is kijavított úton döngetek negyvennel, a lejtökön urambocsá' hatvannal. Így késő délután, látva, hogy a bankigazgató úr kocsijának a motorját a negyven fokos hőségben már melegíti az akkurátus libériás sofőr, sajnos a bank zárása után pár perccel, Bubá-ba érkezve ünneplem az aszfaltot és azt is, aki feltalálta. A központban Uszmán Aga általános és nagykereskedő boltjában némi félreértést, sértődést és vitát követően egy darab amerikai zöldhasú százasért bezsebelek ötvenháromezer CFA-t. Gazdag vagyok! Gyorsan beruházok egy indiai gyártmányú rovarirtó sprayre és ezerötszáz CFA kártyafeltöltésre.

Éjjel a Rio Grande partján a kedvenc, már-már megszokott helyen, a napelemesledes köztéri lámpa alatt az autó forró bádogkasztnijában a párás hőségtől és a chemotoxtól felváltva ájuldozok és fulladozok, a szúnyogok és egyéb rovarok az elgázosítás után egy ideig felháborodva, dühödten dunnyognak, majd többségük örök álomba zuhanva elhallgat, igaz a torkom sem úszta meg, jól megmarta a szer.

Reggel a környékbeli Nemzeti Park szemközti irodájába tartó elegáns-tiszta dolgozók aggódva faggatnak, hogy minden rendben van-e velem? Persze, az este 
érkeztem vissza Sao Joao-ból. Elismerően bólogatnak, csak azt nem értik, sőt el sem hiszik, hogy ezzel a tyúkketrec méretủ kék bádogdobozzal jártam arrafelé. Ezt a nemzeti parkot ugyan nem ajánlják, autóval és kerekesszékkel is egyaránt hozzáférhetetlen, de ha csimpánzokkal akarok haverkodni és rászánok egy hetet, mindenképp menjek le délre a Cantanhez NP-ba. Miért is ne?

A reggelit átaludtam, a hektikusan szétszórt belvárosban ebédre a kedvenc hússütödében rendelek kis adag, ezer CFA-t kóstáló, takarosan tenyérnyire szaggatott barna cementes-zsák darabkákba csomagolt kecskehúst. Fele csont, fele szén, fele mócsing, de én valamiért imádom: ezen a környéken nekem ez a meleg étel, a civilizáció emléke a sült hús. Külön értékelem, hogy a cementes-zsákokat is újra felhasználják. A városban nincs rendes benzinkút, a körforgalomnál a vörös porba mumifikálódott roncsok mellett árválkodó konténerből némi felárral megtankolok, majd a városka szélén az iskola kútjánál gyermekek telepumpálják az összes vizes demizsont, kisebb-nagyobb pillepalackot, még a szolár zuhanyt is. Szomjan, az már biztos, hogy legalább egy hétig nem halok! Nincs nálam semmi csemege, így a gyermekeknek, megszegve a szokásjogot, a kezükbe nyomok némi készpénzt. A lelkükre kötöm, hogy ne adják oda senkinek, ez az övék, zsebpénz. Látom a döbbenetet az arcukon, hallják, de nem értik, amit mondok. Errefelé a gyermeknek nincs tulajdona.

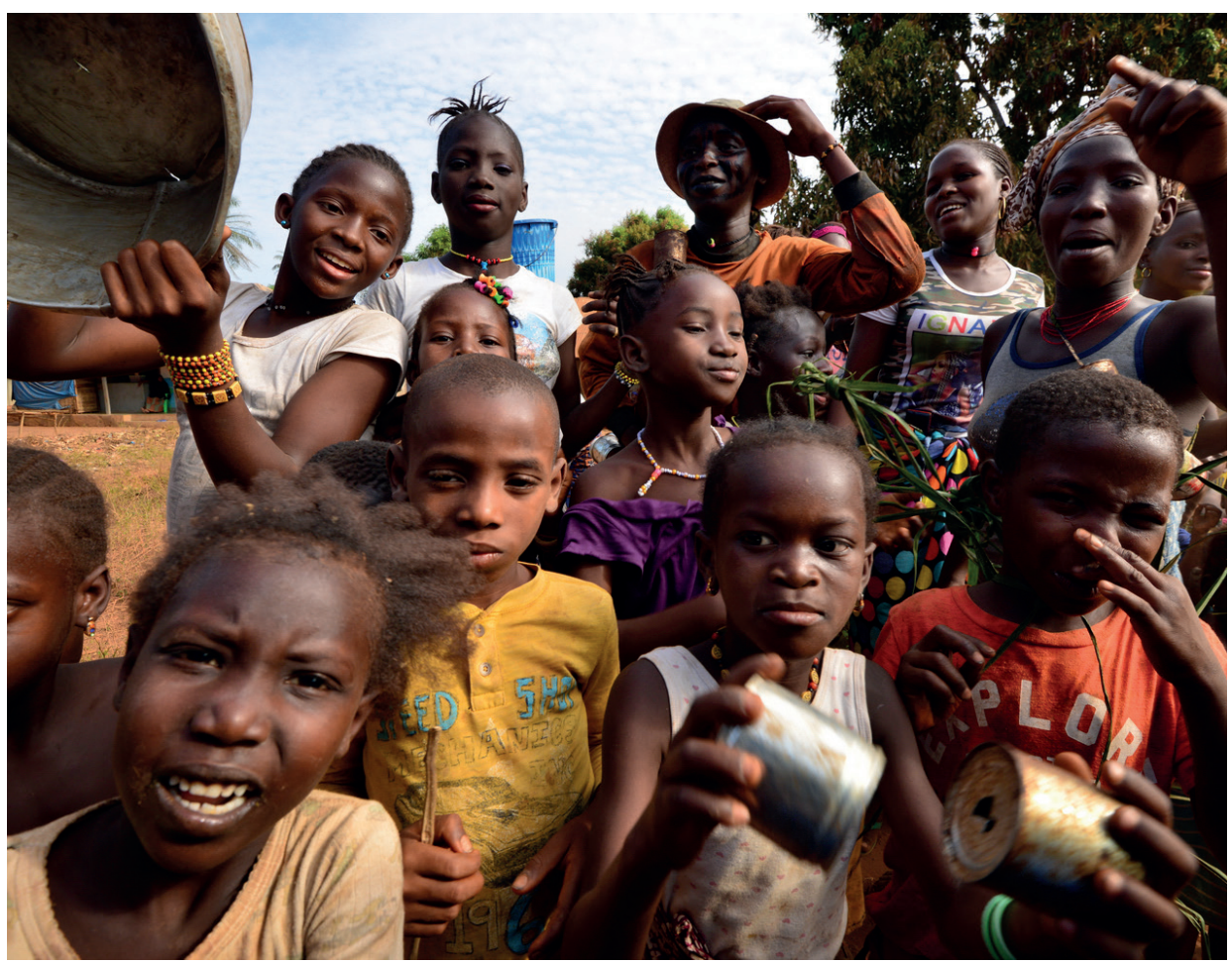


Az aszfaltút, bár gyakorlatilag ugyanaz, mint amelyiken errefelé kátyúról-kátyúra káromkodtam végig, most a Sao Joao utáni embert és autót próbáló erdei szakasz után majdhogynem Stockholm külvárosában érzem magam, a Jimny szelepei is fütyörészve falják a kilométereket.

Mampata-nál némi kérdezősködés után balra fordulok, a ritkán erre tévedő cserkészek kedvéért földre rogyott táblán kifakult hangyányi felírat is mutatja, hogy a Nemzeti Park még ötvennégy kilométer. Kifutópálya szélességü kifogástalan bogárhátú vörös piszten krúzolok, nem sietek, az ablakban könyökölve hitetlenkedve élvezem a futómü felől áradó békés csendet, a gyengéden perzselő forróságot, a dzsungel soha véget nem érő madár-áriáját. Az első hidacska után hatalmas csattanással ér véget az idill és kecskebuka ugratással visszatér a nem igazán hiányolt saojoai útminőség, elengedem a gázt, gyalogostempóra lassítok, megnyugtatom magam, hogy szép volt ez a pár nyugodt és csendes kilométer, de így nevetségesen könnyü lenne az utazás.

Az út szélén motort szerelnek, megállok, hátha segíthetek. Elszakadt a lánc. Vontatókötélre veszem a motorosokat, nem nagyon tartják feszesen a kötelet, össze-vissza rángatom őket, többször majdnem felbuknak. Párszor megállok, újra és újra elmondom nekik, hogy a kötélnek feszesnek kell lenni, bólogatnak, de aztán feladom. Mivel a sírgödör méretủ kátyúknál majdnem meg kell állnom, kétszer ráfutnak a vontatóra, a hátsó kerék feltekeri a montecarloi Decathlonban vásárolt statikus hegymászó kötelet, felborulnak. Mivel nagyon figyelek, többnyire elöre, de pár pillanatonként hátra is, nem húzom őket túl sokáig motorostól a földön fekve a porban. Bánom, hogy hátul nincs szemem, mert ezen a kátyús-szántásos úton nem ártana, ha egyszerre mindent látnék. A repedések miatt állandóan lassítgatnom kell, össze-vissza csalinkáznak, dülöngélnek, pattognak mögöttem a motoron, de zokszó nem esik. Nem nagy élmény, pattanásig feszült idegekkel figyelek mindenfelé.

Adott pillanatban hátul veszettül integetnek, kiderül, hogy megérkeztünk a szerelőhöz. Hitetlenül tekergetem a nyakam, de én csak mangófákat és pár kunyhót látok mindkét oldalon. Visszatolják egy darabon a vasat, követem őket, beállok én is az árnyas ökocsarnokba, ahol egy félmeztelen fiatal csávó pár perc alatt megjavítja a láncot és

A reggelit átaludtam, a hektikusan szétszórt belvárosban ebédre a kedvenc hússütődében rendelek kis adag, ezer CFA-t kóstáló, takarosan tenyérnyire szaggatott barna cementes-zsák darablkákba csomagolt kecskehúst. Fele csont, fele szén, fele mócsing, de én valamiért imádom: ezen a környéken nekem ez a meleg étel, a civilizáció emléke a sült hús. 
embereink nagyban hálálkodva tovább robognak dél felé. Példátlanul, még azt is megkérdezik, hogy nekem tartoznak-e valamivel? Nem sietek, maradok egy kicsi ideig, beszélgetek a srácokkal, bámulom az egyszerủ szerszámokat, a boszorkányos ujjakat. Ebédszünetet tartanak, kontraposztóban állva esznek, mint a lovak. A Conakry illetőségủ mester illendőségből engem is megkínál a gyanús színü és szagú kásával, majd megdöbbenve figyeli, ahogy az agadiri, nagyon sokszor újra és újra felhasznált mekis müanyag villával jóízüen falatozok. Valamivel odébb nagy ricsajra leszek figyelmes, félrehúzok, hát éppen a 'konzervdoboz és bádogfedő mezítlábas band' ad délutáni koncertet. Nem szállok ki, közelebb húzódnak. A fülembe, a szívembe csattogtatnak, énekelnek, bömbölnek, nevetnek a cikornyásan festett falusi zenészek.

Néhány órányi autós kecskebukázás után végre történik valami: elágazáshoz érkezek. Csimpánzfotóval illusztrált tábla mutatja, hogy Iemberem, ahol a Cantanhez NP központja van, jobbra tizennyolc kilométer. Hiszem is meg nem is, egyébként is csatakos hullafáradt vagyok, egyelöre átgurulok a Jimny-vel a szemközti portára, itt az ideje szocializációt elősegítő, tejes kávénak való forróvizet kunyerálni. A kínai, esetleg indiai valódi műanyag szőnyegen üldögélő-heverő narancsszínủ ruhás fiatalember előtt majdnem-okostelefon, öngyújtó, vágott dohány és olvasó gyöngyfüzér hever, itt nyilván ő a házigazda, hozzá intézem udvarias köszöntésem és szavaim. Örül nekem, kérésem továbbítja a mögötte ülö Sir feliratos fiatalembernek, aki továbbmondja a mellette álló színes szoknyás fiatalasszonynak, akinek egy pár rózsaszín babatalp kandikál ki a hóna alól. Pár perc múlva hátramegy a pirosruháskékturbános nagymamához, aki készségesen pattan fel és gyújt tüzet.

Jó, hogy megálltam kérdezősködni, mert a múlt században a táblát a rozsda megette, néhány évig a földön hevert, de aztán össznépi összefogással újra felállították, és azóta rossz irányba mutat. Ezt mindenki tudja, mondja a heverésző férfi nevetve, de nagyon odafigyelnek, hogy az erre tévedő turistákat erről tájékoztassák. A NP menedzsere, akivel később lesz alkalmam megismerkedni, a Sir márkájú fiatalúrnak még egy eredeti kínai motort is kölcsönadott, hogy az ellenkező irányban csellengő külföldieket jó útra térítse. Régóta vagyok úton, sokszor nevettek már ki, ezért nehezen, de mégis magamban tartom azt a kézenfekvő kérdést, hogy nem lehetne-e a következő nagy vihar után vagy alatt a táblát suttyomban visszafordítani a helyes irányba?!

Az elkészült tejeskávét az ütött-kopott narancssárga fémpohárban körbeadom, mindenki megkóstolja, ugyan el nem sápadnak, nem is tudnának, ha akarnának sem, de nem szólnak egy szót sem, csak a nagymama köpi ki nagy őszinte sugárban a vörös földre. Innen Iemberem-ig nem lesz több elágazás, és elégséges útbaigazítást kaptam, a motoros fiatalúr, akivel a következő napokban még kétszer összefutok a bozótban és a dzsungelben, mégis ragaszkodik hozzá, hogy egy darabon elkísérjen, nehogy eltévedjek. Lelke rajta, ezen nem múlik. 

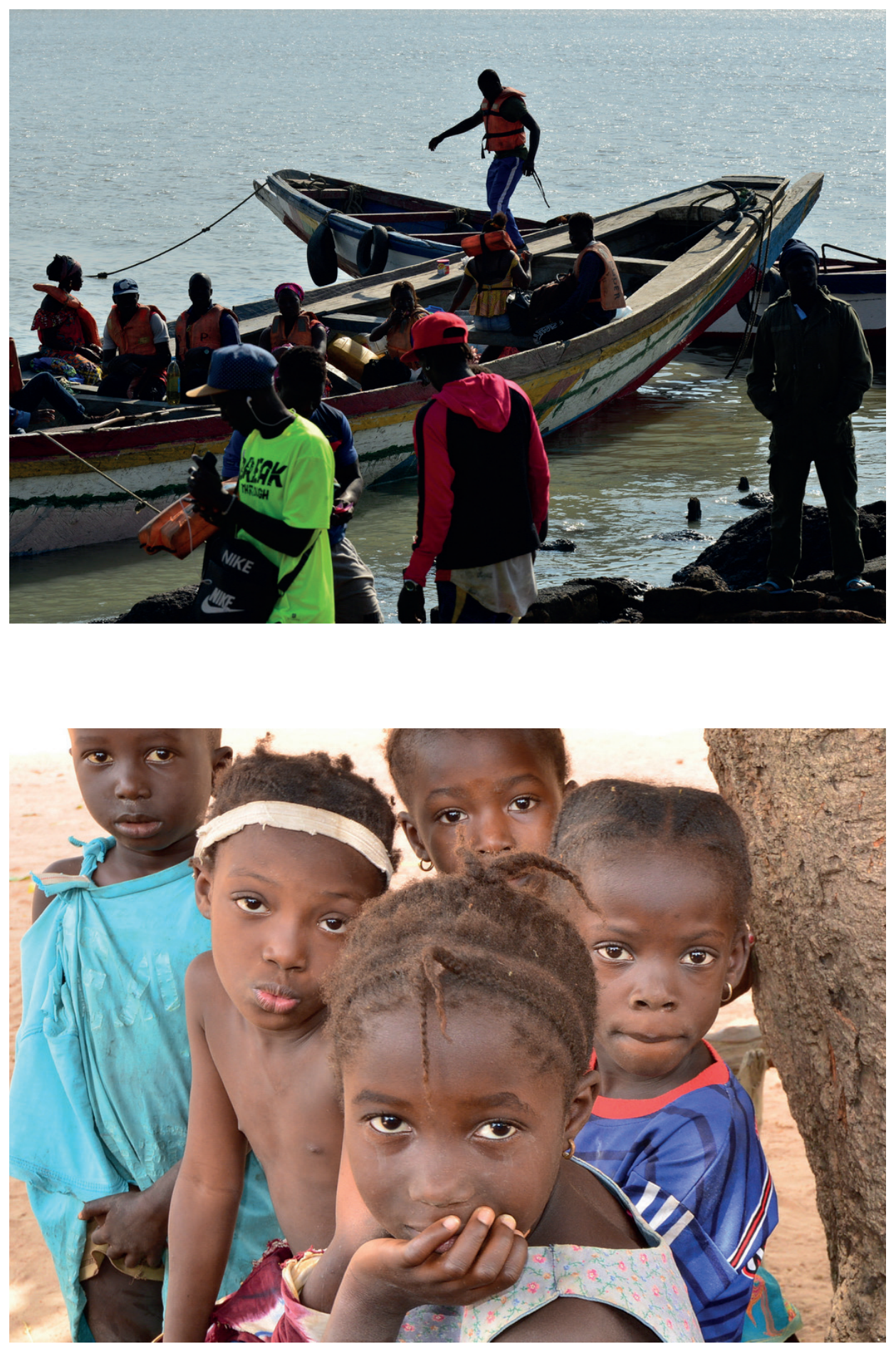

Nagy Bendegúz Lóránd: Valahol a milliónyi kesudiófa árnyékában... 
Ma úriemberhez méltón, kényelmesen szeretnék aludni, úgyhogy késő délután, még a vérszívók támadása előtt félrehúzok az út mellett egy nagyjából vízszintes, homokos, de eléggé kemény placcon, hogy felállíthassam a tábori ágyat. Átellenben házak lapulnak a fák alatt, énekszót hallok, pár perc múlva pedig egy piros pólós, színes-kockás abroszba burkolózott férfi átjön, pár méterre megáll és karba tett kézzel bámul. Népes sereg, asszonyok és gyermekek követik kis időn belül, közelebb nem jönnek, szóra, beszédre nem reagálnak, csak állnak és moziznak, némán figyelik, ahogy a furcsa fehér ember felállítja a tábort, vacsorázik, olvas, naplót ír. Bekapcsolom a zenét, a majd' húsz éves Jimny-ben még eredeti Panasonic kazettás magnó nyekereg, Tankcsapdát hallgatunk, de nem reagálnak, nem csápolnak. A Metallica sem váltja ki belölük a megszokott hatást, megállapítom, hogy a kulturális különbség fogalma nem légböl kapott.

Esteledik, a kesudiófák ágaiba már belegabalyodott a vérvörös nap, de ök mindig itt álldogálnak, bár már egy fél órája kántálom, hogy a holnapi viszontlátásra, jó éjt. Viccből az összes általam beszélt nyelven mindent megismétlek, a gyermekek kuncognak, de lábuk nem mozdul, szemük se rezdül. A szükség is elkap, előveszem a kempingvécét, kinyitom, a kocsi túloldalán felállítom, mondom, mutatom, hogy mire készülök, de nem nagyon hatja meg őket, így nem marad más hátra, mint gatyát letolni, átülni és élvezni a kilátást. Eszembe jut, hogy odahaza is, amikor nem volt zár az akadálymentes WC-n, előfordult, hogy felrántották az ajtót és rámbámultak a vécén trónolva, sőt olyan is megesett, hogy mielőtt egy rám törő anyukára rádörrenhettem volna, hogy 'Foglalt!', zavarában megelőzött és megkérdezte, hogy segíthetne-e valamit? Azzal nyugtatom magam, hogy ez itt majdnem ugyanaz a helyzet, csak a falak és a közös nyelv hiányzik.

Közben besötétedett, felkapcsolom az autó elülső szúrófényeit, a gyermekek, mint az éjjeli lepkék a fénybe telepednek. Hullafáradt vagyok, de nem állom meg, hogy

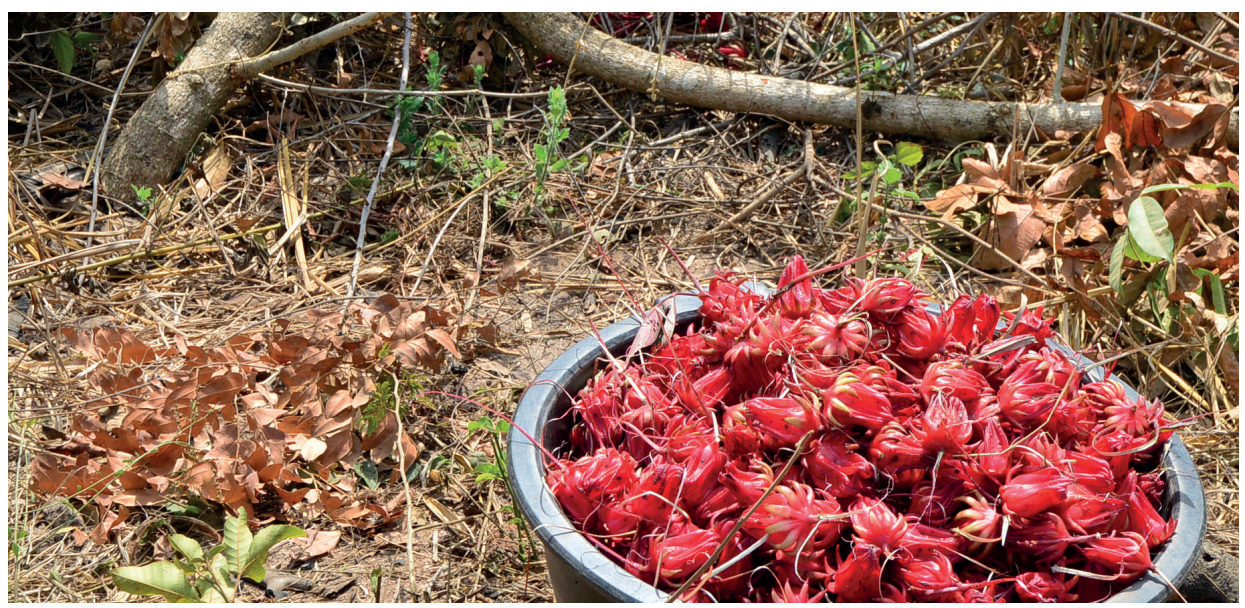


ne vegyem elő a fényképezőt. Fekszem az ágyban, istentelenül jólesik végre kinyújtóztatni fájó tagjaimat az est hüvös sötétjében. A férfit már nem látom, de hallom, ahogy a szúnyogokat csapkodja a vaksötétben, a gyermekek itt gyültek össze az ágy körül. Előveszem Audrey Hepburn életrajzát, magam sem tudom miért, de épp ezt olvasom. Odahaza egy pár könyvet felmarkoltam a szokásos Ady összes mellé. Hangosan olvasok fel nekik. Közelebb húzódnak, paskolják, lökdösik egymást, kuncogva-csivitelve hallgatják a fura idegen nyelvét. Elalvás elött még valahol nagyon messze a bozótban hallom a csimpánzhorda hangosan tomboló őrjöngését, a közelben makákók gúnyos-nevetve száguldoznak az ágak között.

Itt a köderdőben zuhanyozni sem kell, elég hajnalban kitakarózni, fekve körbefordulni, testet lecsutakolva megtörölközni, majd visszabújni a meleg és vízhatlan hálózsák belsejébe. Merő csavaró víz minden, ami kint maradt, a sürün gomolygó pára fél tíz körül kezd szétoszlani, majd a Nap teljes intenzitással birtokba veszi a harmatos világot.

Reggel, mintha mi sem történt volna, a történet ugyanúgy folytatódik, népes sereg figyeli minden mozdulatomat. A szótlan férfi némelyik gyermekre rádörren, majd fél kézzel az abroszt markolva nyomatékosan fenékbe is billenti őket, gondolom, hogy a szerencséseknek ideje iskolába menni. Az úton időnként nagy ovációval gyermeksereg vonul iskolába. Láttomra meghökkennek, földbe gyökerezve megállnak, de a férfi karját fenyegetően emeli rájuk, mire újra meglódulnak a suli irányába. A tudományra kevésbé fogékonyak vagy talán csak kevésbé szerencsés gyermekek a közeli bozótban hosszú, rugalmas pecabottal gyümölcsöt vernek le, megreggeliznek, majd letépnek egy hosszú liánt, ami még közelről is decathlonos kötélnek néz ki és lelkesen ugróköteleznek.

Szép lassan, hogy nagyon ne izzadjak meg, én is összecuccolok: várnak a csimpánzok!

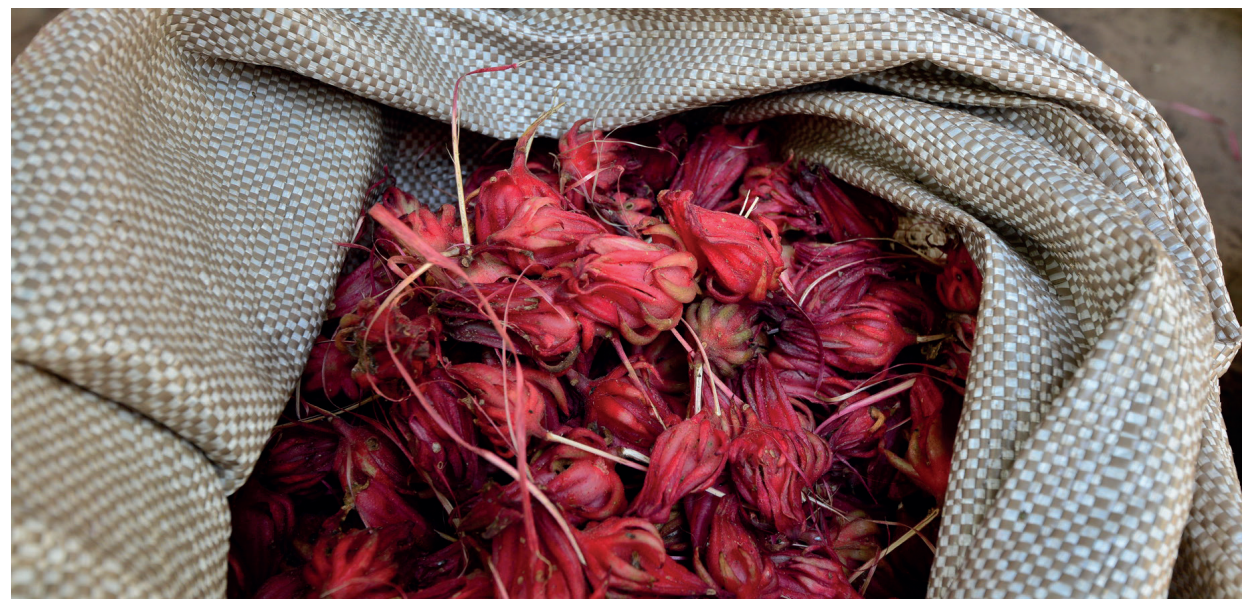




\section{publikon}

Klemensits Péter

PÁNCÉLOS HÁBORÚ ÉSZAK-AFRIKÁBAN

1940-1943

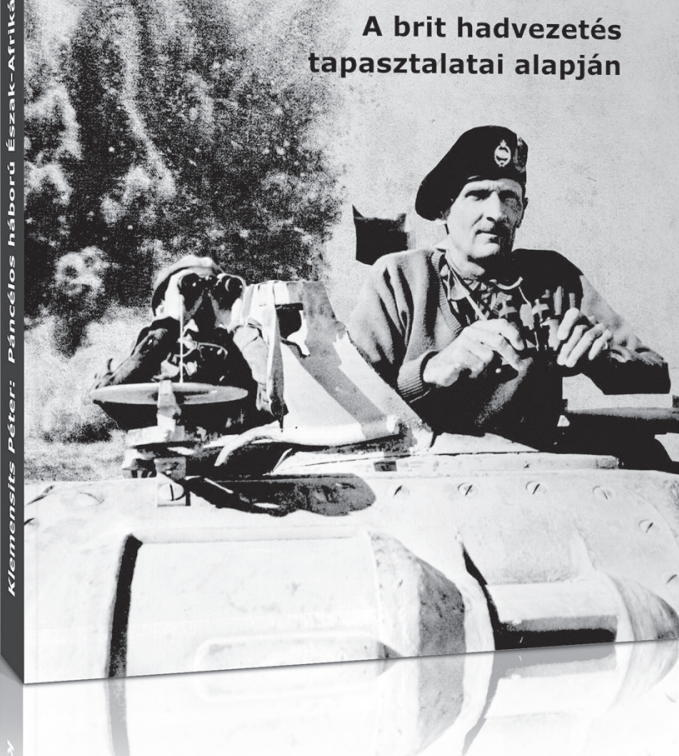

Klemensits Péter

\section{Páncélos háború Észak-Afrikában (1940-1943)}

A háborús hadszínterek közül mindig is az észak-afrikai volt a legkülönlegesebb, különösen az európaiak számára. Az ókori titkok, a hatalmas ismeretlen, a kietlen sivatagok, a kutatók és a hadtörténet rajongók figyelmét is felkeltették az évek során, korántsem véletlenül. A második világháború során olyan parancsnokok szereztek maguknak hírnevet ezen a hadszíntéren, akiket előtte kevésbé ismert a közvélemény, mint pl. Erwin Rommel vagy Bernard Montgomery. A harckocsi, páncélos pedig nem véletlenül lett az afrikai harcok emblematikus harceszköze.

A kötet tudományos igényességgel foglalja össze mindazon összetevőket, melyek végigkísérték brit páncéloserók alkalmazását Észak-Afrikában 1940-1943 között, különös tekintettel a brit északafrikai hadvezetés hadászati és hadmúveleti tervezésére, a főbb hadmúveletek bemutatására és a páncéloscsapatok alkalmazásához köthető tanulságok összegzésére. A páncélos fegyvernem alkalmazásán túl viszont az egész észak-afrikai hadszíntér legfontosabb - de kevésbé feldolgozott stratégiai problémái is megjelennek a kötetben, nevezetesen, hogy az olaszok feletti győzelem után miként változott meg a hadászati környezet a britek hátrányára 1941 tavaszán, majd pedig 1942 elején, ez pedig milyen következményekkel járt Észak-Afrikára és a Közel-Keletre nézve, továbbá melyek voltak azok a hadászati döntések, melyek az 1943-as hadmúveletek befejezéséhez vezettek.

Keresse a kötetet a Líra Könyvesboltokban,

a független könyvesboltokban és az internetes portálokon

vagy rendelje meg a Publikon Kiadótól a www.publikon.hu oldalon. 